\title{
Bir Depo Tesisine Alınacak Paketleme Makinesi Seçim Kararının Analitik Ağ Süreci Tabanlı Gri İlişkisel Analiz Yöntemiyle Belirlenmesi
}

\author{
Ayça TÜMTÜRK ${ }^{1}$ ve Beran GÜLÇİÇEK TOLUN ${ }^{2}$
}

\section{$\ddot{O} z$}

Günümüzde, işletmelerin başarılı olmaları sadece kendi performanslarına bağlı değildir. Tedarik zinciri üyelerinin performansı da işletmelerin başarısını doğrudan etkilemektedir. Depo yönetimi lojistik faaliyetlerinin ayrılmaz bir parçasıdır. Depoların en önemli işlevlerinden biri de paketlemedir. Depolarda kullanılan paketleme makineleri işletmelere önemli faydalar sağlamaktadır. Paketleme için en uygun makinenin seçimi işletmelerin birçok değişkeni göz önünde bulundurarak vermesi gereken kararlardan biridir. Bu çalışmada da bir işletmenin depolarında kullanacağı en uygun paketleme makinesine ilişkin karar verme problemi incelenmiştir. Analitik A ̆g Süreci (AAS) ile makine alım kararında etkili olan kriterler ağırlıklandırılmış, Gri İlişkisel Analiz (GİA) Yöntemi ile de kriter ağırlıkları göz önünde bulundurularak üç alternatif makinenin performansı değerlendirilmiştir. Ağırlıklandırmalara göre hız ve duruş süresi gibi kriterler yatırım maliyetinden daha önemli bulunmuştur. Değerlendirme neticesinde AAS'den gelen ağırlıklarla hesaplanan ve eşit ağırlıklarla hesaplanan gri ilişkisel dereceler birbirinden farklı çıkmış ve farklı alternatiflerin seçilmesi gerektiği görülmüştür.

Anabtar Kelimeler: Analitik Ağ Süreci Gri İlişkisel Analiz, Makine Seçimi

\section{The Bundling Machine Selection for a Warehouse Facility Using Analytical Network Process Based on Gray Relational Analysis Method}

\section{Abstract}

Nowadays, business success does not only depend on firm's performance, but also depends on the performance of the chain supply members who affect the success of the businesses directly. One of the inseparable parts of logistics is warehouse management. Moreover, bundling is a key function of warehouse management. Bundling machines used in warehouses provide significant benefits to businesses. Choosing the most suitable machine for bundling is one of the decisions that businesses should make by considering many variables. This study examined the problem of deciding on the most suitable bundling. By means of Analytical Network Process (ANP), the criteria that were effective in the machine purchase decision were weighted, and the performance of three alternative machines was evaluated with the Gray Relational Analysis (GRA) Method. According to the weighting, criteria, such as speed and downtime were found to be more important than investment costs. As a result of the evaluation, gray relational degrees calculated with weights from AAS and calculated with equal weights were found to be different from each other and it was seen that different alternatives should be selected.

Key Words: Analytical Network Process, Gray Relational Analysis, Machine Selection

\section{Atıf İçin / Please Cite As:}

Tümtürk, A. ve Gülçiçek Tolun, B. (2021). Bir depo tesisine alınacak paketleme makinesi seçim kararının analitik ağ süreci tabanlı gri ilişkisel analiz yöntemiyle belirlenmesi. Manas Sosyal Araştırmalar Dergisi, 10(2), 971-985.

Geliş Tarihi / Received Date: 05.11.2020

Kabul Tarihi / Accepted Date: 18.01.2021

\footnotetext{
${ }^{1}$ Dr. Öğr. Üyesi - Manisa Celal Bayar Üniversitesi İktisadi ve İdari Bilimler Fakültesi, ayca.tumturk@cbu.edu.tr

(iD) ORCID: 0000-0002-7576-2953

2 Dr. Öğr. Üyesi - Manisa Celal Bayar Üniversitesi İktisadi ve İdari Bilimler Fakültesi, beran.gulcicek@cbu.edu.tr

(iD) ORCID: 0000-0002-7552-2351
} 


\section{Giriş}

Günümüz iş dünyasının rekabet ortamı giderek karmaşık bir yapıya bürünmektedir. Bunun sebeplerinden biri internetin herkes tarafindan kullanılması sayesinde e-ticaretin yaygınlaşması ve dünyanın her yerinden müşteri bulmanın getirdiği avantajın yanı sıra, dünyanın her yerinden rakip getirme dezavantajının da bulunmasıdır. Firmalar rekabet için müşteri istek ve ihtiyaçlarını karşılamakla kalmamalı, isteklerin ötesine geçmelidirler. Özellikle zamanında teslimat konusu firmalar arasında ve son müşteriye ulaşmada önem kazanmıştır. Zamanında teslimat yapılması ise tedarik zincirinin entegrasyonuna bağlıdır. $\mathrm{Bu}$ zincirin üyelerinden biri olan depolara büyük iş düşmektedir.

Depolar ara ürün deposundan, soğuk hava depolarına, aktarma merkezlerinden, antrepolara kadar çok farklı çeşitte ve boyutta olabilmektedir. Depoların çeşit ve boyutları ne olursa olsun, tedarik zincirindeki rolleri büyüktür. Depoların işlevlerinden biri de paketleme işlevidir.

Paketleme tüm tedarik zinciri boyunca yer alır. Pazarlama alanında tutundurma çabalarına büyük katkısı olan paketleme lojistik alanında özellikle taşıma ve depolama açısından faydalıdır. Çok küçük boyuttaki ürünlerin elleçlenmesinde ve depolarda tutulmasında paketleme, çalışanlara hız ve kolaylık sağlar. Paketleme çeşitleri çok küçük bir birimin daha büyük bir birime yerleştirildiği ve bu birimin de daha büyük bir birime yerleştirildiği ve bu şekilde sürüp giden blok inşası kavramına göre birincil, ikincil, üçüncül ambalajlama olarak düşünülebilir. Birincil ambalaj ürünü saran ve barındıran ambalaj iken, ikincil ambalaj genelde birincil ambalajları gruplandırmak için kullanılır ve master karton adını taşır. Bu master kartonları elde etmek için birçok sektörde depolarda paketleme makineleri kullanılmaktadır. Paketleme makinelerinin en büyük avantajı çalışan ihtiyacını azaltması ve süreç çevrim zamanını kısaltmasıdır. Bu makineler birbirinden boyut, hız, operatör ihtiyacı, yatırım maliyeti gibi birçok kriter açısından farklılaşırlar. Bu nedenle firmalardaki depo yöneticileri ve operasyon yöneticileri bu büyük satın alma kararını verirken, birçok kritere göre hareket ederler. Farklı kriterleri göz önünde bulundurarak en uygun makinenin seçilmesi işletmeler için çok kriterli karar verme problemlerinden biridir. Bu çalışmada ilaç sektöründe faaliyet gösteren bir depo yöneticisi ve proje ekibine, depoda kullanılacak paketleme makinesi seçimi için çok kriterli karar verme tekniklerinden olan Analitik Ağ Süreci ve Gri İlişkisel Analiz yöntemleri kullanılarak yardımcı olmak amaçlanmıştır.

Çalışmanın ilk bölümü olan yöntem bölümünde; çalışmada kullanılan Analitik Ağ Süreci ve Gri ilişkisel Analiz yöntemlerinin aşamaları anlatılmıştır ve makine seçimi, Analitik Ağ Süreci ve Gri İlişkisel Analiz ile ilgili literatüre yer verilmiştir. Sonrasında uygulama bölümü yer almaktadır. Uygulama bölümünde bir depo tesisine alınacak paketleme makinesi seçim kararının verilmesi ile ilgili bilgiler yer almaktadır. Uygulama bölümünde ayrıca akış diyagramı gösterilmiştir. Verilerin analizini takiben bulgular bölümüne yer verilmiştir ve çalışmanın son bölümde de tartışma, sonuç ve öneriler yer almaktadır.

\section{Yöntem}

Bu çalışmada alternatifler arasından en iyi paketleme makinesi seçimi amacı ile çok kriterli karar verme tekniklerinden analitik hiyerarşi prosesi ve analitik ağ süreci teknikleri değerlendirilmiş, kriterler arasında da ilişki olmasından hareketle Analitik Ağ Süreci yönteminde karar kilınmıştır. Problemin sübjektif bilgi içermesinden dolayı alternatifler arasından en iyi makinenin seçilmesinde Analitik A $\breve{g}$ Sürecinden gelen ağırlıklar kullanılarak, belirsizlikte iyi çalışan yöntemlerden biri olan Gri İlişkisel Analiz yöntemi kullanılarak karar verilmiştir.

\section{Analitik Ağ Süreci}

Analitik ağ süreci (AAS), ağıll1kların hesaplanması ve önceliklerin belirlenmesi amacıyla Saaty tarafindan geliştirilen çok kriterli karar verme (ÇKKV) yöntemidir (Kabak ve Dağdeviren, 2017, s. 11). ÇKKV, karar verici ya da karar vericilere, birden fazla alternatifin olduğu ve bu alternatiflerin birden fazla kritere göre değerlendirilmesi gerektiği durumlarda yardımcı olan TOPSIS, AHP, AAS, ELECTRE vb. birçok yöntemi içermektedir. ÇKKV yöntemleri matematiksel algoritmalara dayandı̆̆ından objektif, karar vericilerin yargılarından yola çıkıldığından dolayı ise sübjektif yöntemler olarak değerlendirilmektedir (Çakır ve Perçin, 2013, s. 450).

AAS, 1977 yllında yine Saaty tarafından geliştirilen Analitik Hiyerarşi Prosesi (AHP)'nin daha genel bir formudur. İki yöntem de akademik literatürde sıklıkla kullanılan yöntemlerdendir. Bu yöntemler arasında bazı farklılıklar mevcuttur. İlk geliştirilen yöntem olan AHP'de ilişkiler hiyerarşik bir yapıya göre sıralanır. Bu yapıya göre kriterler arasında bir ilişkiden ya da alternatiflerin de kriterleri etkileyebileceğinden 
söz edilmez. Bu nedenle özellikle karar verme probleminde bu tür ilişkiler mevcutsa, sadece aşağ1 yönlü okların/ilişkilerin bulunduğu hiyerarşik bir yapıdan ziyade, yukarı yönlü ya da çift taraflı okların da kullanılabildiği, kriterler arasındaki ilişkilerin ve alternatiflerin kriterleri etkileyebildiği ilişkilerin gösterildiği ağ yapısının oluşturulması gerekir. AAS'nin yapısı da AHP'den farklı olarak Şekil 1'de de ifade edildiği gibi bu gösterime izin vermektedir.

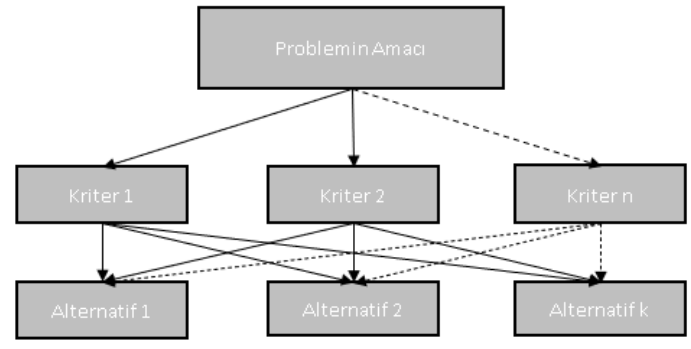

(AHP)

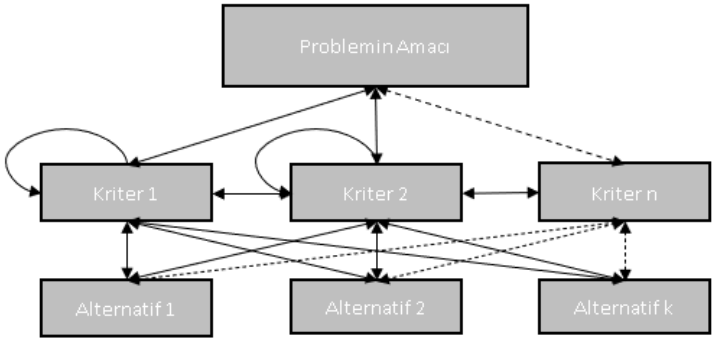

(AAS)

Şekil 1. AHP ve $A A S$ yapular

AAS yönteminin uygulanması 4 aşamada özetlenebilir (Hashemi vd., 2015, s. 82; Ömürbek ve Şimşek, 2014, s. 309):

\section{Assama 1: Problemin Tanımlanması ve Modelin Olusturulması}

İlk olarak problemin ne olduğu belirlenir. Problem sonucu seçilecek alternatifler ve bu alternatiflerden hangisinin seçileceğini etkileyen kriterler ve alt kriterlerin belirlenmesi gerekir. Ayrıca bu aşamada hangi kriter/alt kriterlerin birbirini etkilediği de belirlenerek bir ağ yapısı oluşturulur. Böylece model ortaya konmuş olur. Kriterlerin ve aralarındaki etkileşimin belirlenmesi aşaması sübjektif olduğundan, bu aşamanın uzman bir ekip tarafindan yapılması sübjektifliği azaltabilir.

\section{Assama 2: Íkili Katşılaştırma Matrisleri ve Özvektötlerin Oluşturulması}

Kriterler, alt kriterler, alternatifler ve aralarındaki ilişkinin gösterildiği ağ yapısı kurulduktan sonra, aralarında ilişki olan kriter/alt kriterlerin ikili karşılaştırması yapılır. Bu karşılaştırma yapılırken Saaty'nin 19 ölçeğinden yararlanılır (Tablo 1). İki faktörün karşılaştırmasında ekip üyeleri ortak bir karar alıp önem derecelerini belirleyebilir. Ya da ekip üyelerinin her biri bireysel olarak önem dereceleri belirler ve bu değerlerin geometrik ortalaması alınır.

Tablo 1. Saaty Ölçĕgi Değerleri

\begin{tabular}{ll}
\hline $\begin{array}{l}\text { Önem } \\
\text { Değerleri }\end{array}$ & Değer Tanımları \\
\hline 1 & Her iki faktörün eşit öneme sahip olması durumu \\
3 & 1. faktörün 2. faktörden daha önemli olması durumu \\
5 & 1. faktörün 2. faktörden çok önemli olması durumu \\
7 & 1. faktörün 2. faktöre nazaran çok güçlü bir öneme sahip olması durumu \\
9 & 1. faktörün 2. faktöre nazaran mutlak üstün bir öneme sahip olması durumu \\
$2,4,6,8$ & Ara değerler \\
\hline
\end{tabular}

Kaynak: Saaty 1986, s. 843

İkili karşılaştırma matrisleri oluşturulurken 1. faktörün 2. faktöre göre önemini gösteren değer $a_{12}$ iken, 2. faktörün 1. faktöre göre önemini gösteren $a_{21}$ değeri $1 / a_{12}$ 'ye eşittir. Bu matrisler oluşturulduktan sonra özvektörlerin oluşturulması ve tutarllı1k analizlerinin yapılması gerekir.

İkili karşılaştırma matrislerinin özvektörlerinin hesabında öncelikle her bir sütun elemanı sütun toplamına bölünerek normalizasyon işlemi yapılır. Yeni elde edilen matristeki satır bileşenlerinin aritmetik ortalaması ise o satırın özvektörünü (W) verir. Özvektörler bir sütun vektörü olarak aşağıdaki gibi gösterilir. 
$W=\left[\begin{array}{c}w_{1} \\ w_{2} \\ \cdot \\ w_{n}\end{array}\right]$

İkili karşılaştırma matrislerinin oluşturulmasında karar vericilerin ortaya koyduğu değerlendirmelerin tutarlı olup olmadığının belirlenmesi için tutarlılık analizi yapılır. Bu analizde tutarlılık göstergesi (CI) hesaplandıktan sonra bu değer kullanılarak tutarlı1ı oranı (CR) hesaplanır. CI hesaplanırken ikili karşılaştırma matrisi ile özvektör çarpılır ve elde edilen sütun vektörünün her bir elemanı ona denk gelen özvektör değerine bölünür. Elde edilen değerlerin aritmetik ortalaması ise lamda $(\lambda)$ değerini verir. CI hesabında aşağıdaki formül kullanılır.

$$
C I=\frac{\lambda-n}{n-1}
$$

Bu formüldeki n değeri, işlem yapılan matristeki karşılaştırılan faktör sayısıdır. $\mathrm{n}$ için işlem yapılan matrisin boyutu da denebilir. CI değeri bulunduktan sonra CR değeri hesaplanır. CR hesabında aşağıdaki formül kullanilır.

$C R=\frac{C I}{R I}$

$\mathrm{Bu}$ formüldeki RI değeri matrisin boyutuna göre değişen değerler alır. RI değeri için Saaty'nin geliştirdiği Tablo 2'deki değerler kullanılır.

Tablo 2. RI Dę̆erleri

\begin{tabular}{|c|c|c|c|c|c|c|c|c|c|c|c|c|c|}
\hline $\mathrm{n}$ & 3 & 4 & 5 & 6 & 7 & 8 & 9 & 10 & 11 & 12 & 13 & 14 & 15 \\
\hline RI & 0,58 & 0,90 & 1,12 & 1,24 & 1,32 & 1,41 & 1,45 & 1,49 & 1,51 & 1,48 & 1,56 & 1,57 & 1,59 \\
\hline
\end{tabular}

Kaynak: Saaty, 2005

Hesaplanan tutarlılık oranının 0,10'dan küçük olması beklenir. Eğer bu değer 0,10'dan büyükse tutarlılıktan söz edilemez. Bu durumda sözü geçen ikili karşılaştırma matrisi tekrar oluşturulmalıdır.

\section{Asama 3: Limit Süpermatrisin Oluşturulması}

Tüm özvektörler hesaplandıktan ve tutarlılı analizleri yapıldıktan sonra ilgili satır ve sütunlara denk gelecek şekilde özvektörlerin birleşiminden oluşan süpermatris oluşturulur. Bu süpermatris stokastik değildir. Yani matrisin sütun değerleri toplamı 1'e eşit değildir. Bu matrise başlangıç süpermatrisi ya da ağırlıklandırılmamış süpermatris de denir. Normalleştirme işlemi yapıldıktan sonra ortaya ağırlıklandırılmış matris çıkar. Limit süpermatrise ulaşmak için ağırlıklandırılmış süpermatrisin çok sayıda kuvvetinin alınması gerekir. Kuvvetler alındıkça değerler limit değere yakınlaşır ve limit süpermatris elde edilir. Limit süpermatriste her bir faktörün ağırlığı elde edilmiş olunur.

\section{Asama 4: En İyi Alternatifin ya da Ăgırlıklandırılmış Özelliğin Seçimi}

Limit süpermatris elde edildikten sonra söz konusu problemin çeşidine göre alternatiflerin ağırlıkları ya da kriterlerin ağırlıkları elde edilmiş olunur. Böylece en yüksek ağırlı̆̆a sahip alternatif seçilebilir. Ya da kriterler önem derecelerine göre sıralanabilir. Ayrıca burada elde edilen ağırlıklar, başka bir yöntemde de girdi olarak kullanılabilir.

Literatürde AAS’nin kullanıldığı çok sayıda çalışma bulunmaktadır. Sert vd. (2020) çalışmalarında, Endüstri 4.0 ortamında personelin işe alınması sürecinde gündeme gelen kriterlerin önem derecelerini analitik ağ süreci ile belirlemişlerdir. Matin vd. (2020), işçilerin 1s1 stresi kontrolündeki belirleyici faktörlerin önceliklendirilmesinde AAS'yi kullanmışlardır. Keskin vd. (2020), bulut bilişim güvenlik gereksinimlerine göre en uygun hizmet sağlayıcısını belirlemek amacıyla AAS, AHP ve TOPSIS yöntemini birlikte kullanarak karar verme problemlerinde birden fazla yöntemi bir arada kullanmayı önermişlerdir. Im vd. (2020), yenilikçi iş modellerinin önemini vurgulayarak alternatifler arasından en iyi iş modelini seçebilmek için AAS ile değerlendirme yapmışlardır. Gür vd.(2020), akaryakıt taşımacılığının çevreye olan etkilerini AAS yöntemi ile değerlendirmişlerdir. Giannakis vd. (2020), tedarikçilerin sürdürülebilirlik performanslarını değerlendirebilmek için AAS yöntemini kullanmışlar ve yöntemin TOPSİS ve ELECTRA gibi metotlarla birlikte kullanımını önermişlerdir. Baset vd. (2019), AAS ve VIKOR yöntemini entegre bir 
şekilde kullanarak sürdürülebilir tedarikçi zincirinde tedarikçi seçimi sorununu çözmeyi amaçlamış ve alternatifler arasından en uygun tedarikçiyi belirlemişlerdir.

\section{Gri İlişkisel Analiz}

Gri sistem teorisi Julong Deng tarafindan 1982 yllında geliştirilmiş bir matematiksel yaklaşımdır ve eksik ve belirsiz verilerin olduğu durumlarda bir değerlendirme aracı olarak kullanilır (Sarraf ve Nejad, 2020, s. 2). Deng (1989)'e göre birçok sistem, beyaz, siyah ve gri olmak üzere üçe ayrilır. Bilgisi tamamen biliniyorsa beyaz bir sistem, bilinmiyorsa siyah bir sistem, bilgileri belirsiz olan bir sistem söz konusu ise de gri bir sistemden söz edilir. Gri teoride, sistemde "siyah" durumda olan bilgiyi "gri duruma getirmek amaçlanmaktadır (Özbek,2017, s. 141).

Gri İlişkisel analiz (GİA), Gri sistem teorisi kullanılarak geliştirilmiş, her bir faktörü niceliksel olarak karşılaştıran, derecelendiren bir karar verme tekniğidir (Chang vd., 2003, s. 55). GİA, nicel veri setlerinde kullanılabildiği gibi dilsel değişkenlerin kullanıldığı(nitel) veri setlerine de uygulanabilmektedir. GİA, faktörler arası karmaşık ilişkilerin yer aldığı karar verme problemlerinde uygulanabilen bir yöntemdir. Bu nedenle, çok kriterli karar verme problemlerinin çözümünde tek başına kullanılabildiği gibi diğer yöntemlerle birlikte de kullanılabilmektedir (Yıldırım ve Önder, 2015, s. 231).

Alternatifler, nitel veri setlerine sahip ise, GİA'de bu nitel değişkenlere karşıllk gelen gri sayllar kullanılır. "Her bir gri sistemde gri sayılar, sistem için en temel aşama olarak düşünülebilir. Bir gri sayı, değeri kesin olarak bilinmeyen fakat alabileceği değer için sınırları bilinen/tanımlanabilen bir sayıdır. Gri sayılar bir aralık ya da sayı kümesinden elde edilir" (Aydemir vd.,2013, s. 190). Nitel değiş̧kenlerin karşıllı̆̆1 olarak kullanılan gri sayılar için Tablo 3'te bir örnek görülmektedir.

Tablo 3. Nitel Deŭğşkenlerin Gri Sayı Karşılı̆g

\begin{tabular}{lll}
\hline Değerlendirme & Kısaltma & GriSay1 Karşıı̆ğ1 \\
\hline Çok Zayıf & VP & {$[0,10]$} \\
Zayif & P & {$[10,30]$} \\
Orta Derecede Zayıf & MP & {$[30,40]$} \\
Ortalama & F & {$[40,50]$} \\
Orta Derecede İyi & MG & {$[50,60]$} \\
İyi & G & {$[60,90]$} \\
Çok İyi & VG & {$[90,100]$} \\
\hline \hline
\end{tabular}

Kaynak: Li, vd., 2007, s. 576

GİA yöntemi ile karar verme problemindeki alternatifler için bir sıralama yapabilmek için altı adımdan oluşan bir hesaplama yapmak gerekmektedir (Siyambaş ve Turgut,2020, s. 325, Sarraf ve Nejad, 2020, s. 2; Zuo vd, 2020, s. 2; Özbek, 2017, s. 144):

\section{Veri Setinin Hazırlanması Karat Matrisinin Oluşturulması}

Karar problemi ile ilgili karşılaştırma yapmak için $\mathrm{m}$ adet faktör serisi belirlenir. Alternatiflerin her bir kriter için aldığı değerler eşitlik (1)'de gösterildiği gibi karar matrisi oluşturularak formüle edilir.

$$
\mathrm{X}=\left[\begin{array}{cccc}
x_{1}(1) & x_{1}(2) & \ldots & x_{1}(n) \\
x_{2}(1) & x_{2}(2) & \ldots & x_{2}(n) \\
\vdots & \vdots & \ddots & \vdots \\
x_{m}(1) & x_{m}(2) & \ldots & x_{m}(n)
\end{array}\right]
$$

\section{Karşılassturma Matrisinin ve Referans Serisinin Oluşturulması}

Karar problemindeki faktörlerin kıyaslanabilmesi için gerekli olan referans serisi eşitlik (2)'de gösterildiği gibi formüle edilir ve eşitlik (1)'deki karar matrisine ilk satır olarak eklenerek karşılaştırma matrisi oluşturulur.

$$
x_{0}=\left(x_{0}(j)\right) \text { ve } \mathrm{j}=1,2, \ldots \ldots, \mathrm{n}
$$




\section{Normalizasyon Matrisinin Oluşturulması}

Gri ilişki katsayılarının hesaplanmasında, serilerin karşılaştırılabilmesi için verilerin farklı birimle ölçülmüş olmaması gerektiği için standart hale getirilmesi gerekir. Bu dönüştürme işlemi normalizasyon olarak ifade edilir. Normalizasyon işlemi, serinin özelliğine göre üç farklı şekilde gerçekleştirilir.

Seri değerinin daha büyük olması amacı yani fayda yönlü bir ölçüt söz konusu ise (Örneğin ev satın alma karar probleminde yüz ölçümü kriterine göre aldıkları değerlerin maksimum düzeyde olması istenir) normalizasyonda eşitlik (3) kullanılır. Ölçütlerin maliyet yönlü olması durumunda (örneğin ev satın alma karar probleminde fiyat kriterine göre değerlerin minimum düzeyde olması istenir) eşitlik (4) kullanılarak normalizasyon gerçekleştirilir. Seri değerinin önceden belirlenen bir optimal değere göre normalizasyonu için eşitlik (5) kullanılır.

$$
\begin{aligned}
x_{i}^{*} & =\frac{x_{i}(j)-\min _{j} x_{i}(j)}{\max _{j} x_{i}(j)-\min _{j} x_{i}(j)} \\
x_{i}^{*} & =\frac{\max _{j} x_{i}(j)-x_{i}(j)}{\max _{j} x_{i}(j)-\min _{j} x_{i}(j)} \\
x_{i}^{*} & =\frac{x_{i}(j)-x_{o b}(\mathrm{j})}{\max _{j} x_{i}(j)-x_{o b}(\mathrm{j})}
\end{aligned}
$$

Eşitliklerde verilen $x_{i}(j)$, i. alternatif için j. kriter değeri, $\min _{j} x_{i}(j), j$. kriter için en küçük değer, $\max _{j} x_{i}(j) j$. kriter için en büyük değer olup $x_{o b}(\mathrm{j})$ belirlenen optimal değerdir.

Normalizasyon işleminin ardından karar matrisi eşitlik (6)'da görüldüğü gibi normalizasyon matrisine dönüştürülmüş olur.

$$
\mathrm{X}^{*}=\left[\begin{array}{cccc}
x_{1}{ }^{*}(1) & x_{1}{ }^{*}(2) & \ldots & x_{1}{ }^{*}(n) \\
x_{2}{ }^{*}(1) & x_{2}{ }^{*}(2) & \ldots & x_{2}{ }^{*}(n) \\
\vdots & \vdots & \ddots & \vdots \\
x_{m}{ }^{*}(1) & x_{m}{ }^{*}(2) & \ldots & x_{m}{ }^{*}(n)
\end{array}\right]
$$

\section{Mutlak Değer Tablosunun Oluşturulması}

$x_{0}{ }^{*}$ ile $x_{i}{ }^{*}$ arasındaki farkın mutlak değeri $\left(\Delta_{0 \mathrm{i}}(\mathrm{j})\right)$ eşitlik (7) yardımıyla hesaplanır. Ve eşitlik (8)'deki mutlak değer matrisi oluşturulur.

$$
\Delta_{0 \mathrm{i}}=\left|x_{0}{ }^{*}(j)-x_{i}{ }^{*}(\mathrm{j})\right| \mathrm{i}=1,2, \ldots ., \mathrm{m} \text { ve } \mathrm{j}=1,2, \ldots \ldots, \mathrm{n}
$$

$$
\Delta_{0 \mathrm{i}}=\left[\begin{array}{cccc}
\Delta_{01}(1) & \Delta_{01}(2) & \ldots & \Delta_{01}(n) \\
\Delta_{02}(1) & \Delta_{02}(2) & \ldots & \Delta_{02}(n) \\
\vdots & \vdots & \ddots & \vdots \\
\Delta_{0 \mathrm{~m}}(1) & \Delta_{0 \mathrm{~m}}(2) & \ldots & \Delta_{0 \mathrm{~m}}(n)
\end{array}\right]
$$

\section{Gri Illişkisel Katsayı Matrisinin Oluşturulması}

Eşitlik (9) kullanılarak gri ilişkisel katsayı matrisi oluşturulur. Eşitlikte yer alan $\zeta$ parametresi ayırıcı katsayı olup $[0,1]$ aralığında değerler alır. $\zeta=1$ için ayırıcılık en üst seviyedeyken, $\zeta=0$ için zitlığın olmadığı bir ortam oluşur. Veri farklarının fazla olduğu durumlarda zıtlığı azaltmak için $\zeta$ ayırıcı katsayısı olarak 0'a yakın değerler kullanılmaktadır. Zuo vd.(2020) çalısmalarında ayırıcı katsayı olarak $\zeta=0,5$ değerini kullanmışlardır.

$$
\begin{aligned}
\gamma_{\mathrm{oi}}(\mathrm{j}) & =\frac{\Delta_{\min }+\zeta \Delta_{\max }}{\Delta_{o i}(j)+\zeta \Delta_{\max }} \\
\Delta_{\max } & =\max _{i} \max _{j} \Delta_{0 \mathrm{i}}(j) \text { ve } \Delta_{\min }=\min _{i} \min _{j} \Delta_{0 \mathrm{i}}(j)
\end{aligned}
$$




\section{Gri İliskisel Derecelerin Hesaplanması}

Gri ilişkisel dereceler kriterlerin eşit öneme sahip olmasına ya da ağıllıklandırılmasına bağlı olarak iki farklı şekilde hesaplanır. Eşitlik (10) kriterlerin eşit öneme sahip olduğu durumu ifade etmektedir. Гoi serinin gri ilişski derecesini göstermektedir Eşitlik (11) ise kriterlerin farklı ağırlıklara sahip olduğu durumlarda kullanılır ve eşitlikteki $w_{i}(\mathrm{j})$, kriterin ağırlıklarını göstermektedir.

$$
\begin{aligned}
& \Gamma_{\mathrm{oi}}=\frac{1}{n} \sum_{j=1}^{n} \gamma_{o i}(\mathrm{j}) \quad \mathrm{i}=1,2, \ldots, \mathrm{m} \\
& \Gamma_{\mathrm{oi}}=\sum_{j=1}^{n}\left[w_{i}(j) \cdot \gamma_{o i}(j)\right] \mathrm{i}=1,2, \ldots, \mathrm{m}
\end{aligned}
$$

Gri ilişkisel derecelerin hesaplanmasının ardından, derecelerin büyükten küçüğe sıralanmasıyla en büyük dereceye sahip olan alternatif en iyi alternatif olarak belirlenmiş olur.

Uluslararası ve ulusal literatürde GİA tek başına ya da farklı tekniklerle birlikte kullanarak bir karar verme problemini ele alan farklı çalışmalar bulunmaktadır. Ersoy (2020), Borsa İstanbul ulaştırma endeksinde işlem gören firmalardan sekizinin finansal performansını GİA yöntemi ile ölçmüştür. Demir vd. (2020) çalışmalarında, 18 tane bireysel emeklilik şirketinin performanslarının ölçümü için GİA yöntemini kullanmışlardır. Sridharan vd. (2019) Güney Hindistan'da imalat sektöründe yaptıkları anket sonrasında, sürdürülebilir tedarik zincirindeki risk faktörlerini GİA yöntemi yardımıyla sıralamışlardır. Hashemi vd. (2015), yeşil tedarikçi seçim probleminde AAS ile bütünleşik GİA yöntemini kullanmışlardır. Ayağ ve Yücekaya(2019), en uygun ERP yazılımı seçiminde AHP ile GİA yöntemini birlikte kullanarak en uygun yazılımı belirlemişlerdir. Literatürde, alternatifler arasından en uygun makinenin seçilmesi probleminin çözümü için farklı karar verme tekniklerini kullanan çalışmalar da bulunmaktadır. Karim ve Karmaker, 2016 yılındaki çalışmalarında, AHP ve TOPSİS metotlarını entegre bir şekilde kullanarak, üç makine alternatifi arasından şirket için en uygun olanının seçimi problemini çözüme ulaştırmışlardır. Ertuğrul (2007)'nin bir tekstil işletmesine en iyi tekstil makinesi seçiminde yardımcı olmak amacı ile yaptı̆̆1 çalışmada, bulanık AHP yöntemi kullanılarak yöneticinin karar vermesine yardımcı olunmuştur.

Samvedi vd. (2012), en uygun imalat makinesinin seçimi için Bulanık AHP ile GİA yöntemlerini birlikte kullanmışlardır. Kabak ve Dağdeviren (2017), bir freze makinesi seçimi için, AAS ve GİA yöntemlerini entegre bir şekilde kullanarak uluslararası bir firmanın çok kriterli karar verme problemini çözmesine yardımcı olmuşlardır. Ayağ ve Özdemir 2012 yılında yaptıkları çalışmalarında en iyi makine parçasının seçimi için AAS ve TOPSİ yöntemlerini birlikte kullanmışlardır. Kriter ağırlıklarını hesaplamak için AAS yöntemini kullanmış ve allternatiflerin sıralandırılmasında TOPSİs yönteminden faydalanmışlardır. Kumru ve Kumru (2014) yaptıkları çalışmada bir kalıp imalat şirketi için 3D koordinat ölçüm makinesi seçiminde kriter ağırlıklarının belirlenmesi ve en iyi alternatifin seçilmesi için bulanık AAS yöntemini kullanmışlardır. Bu çalışmada bir depo tesisine alınacak paketleme makinesi seçim kararının verilmesi için AAS ve GİA yöntemleri entegre bir şekilde kullanılmıştır.

\section{Bir Depo Tesisine Alınacak Paketleme Makinesi Seçim Kararının Verilmesi}

Bir ilaç firmasının İstanbul'daki deposunda bulunan makinenin yetersiz kalması sebebiyle paketleme operasyonlarında sıkıntılar yaşanmaktadır. Bu makine kapasite olarak yetersiz olmasının yanı sıra çok sık bozulmaktadır. Ayrıca depoda çalşsan personelin büyük bir kısmı paketleme operasyonuna yardımcı olmak zorundadır. Firmanın deposundaki paketleme operasyonunda yaşanan sorunların çözülmesi için paketleme makinesi alımına karar verilmiştir. Alternatiflerin belirlenmesi ve arasından en doğru seçimin yapılabilmesi için öncelikle bir proje takımı oluşturulmuştur. Takımın kurulması, veri toplama, hesaplamaların ve seçimin yapılması kısımları izleyen bölümlerde verilmiştir. Ayrıca problemin çözümü için izlenen aşamalar Şekil 2'de verilmiştir. 


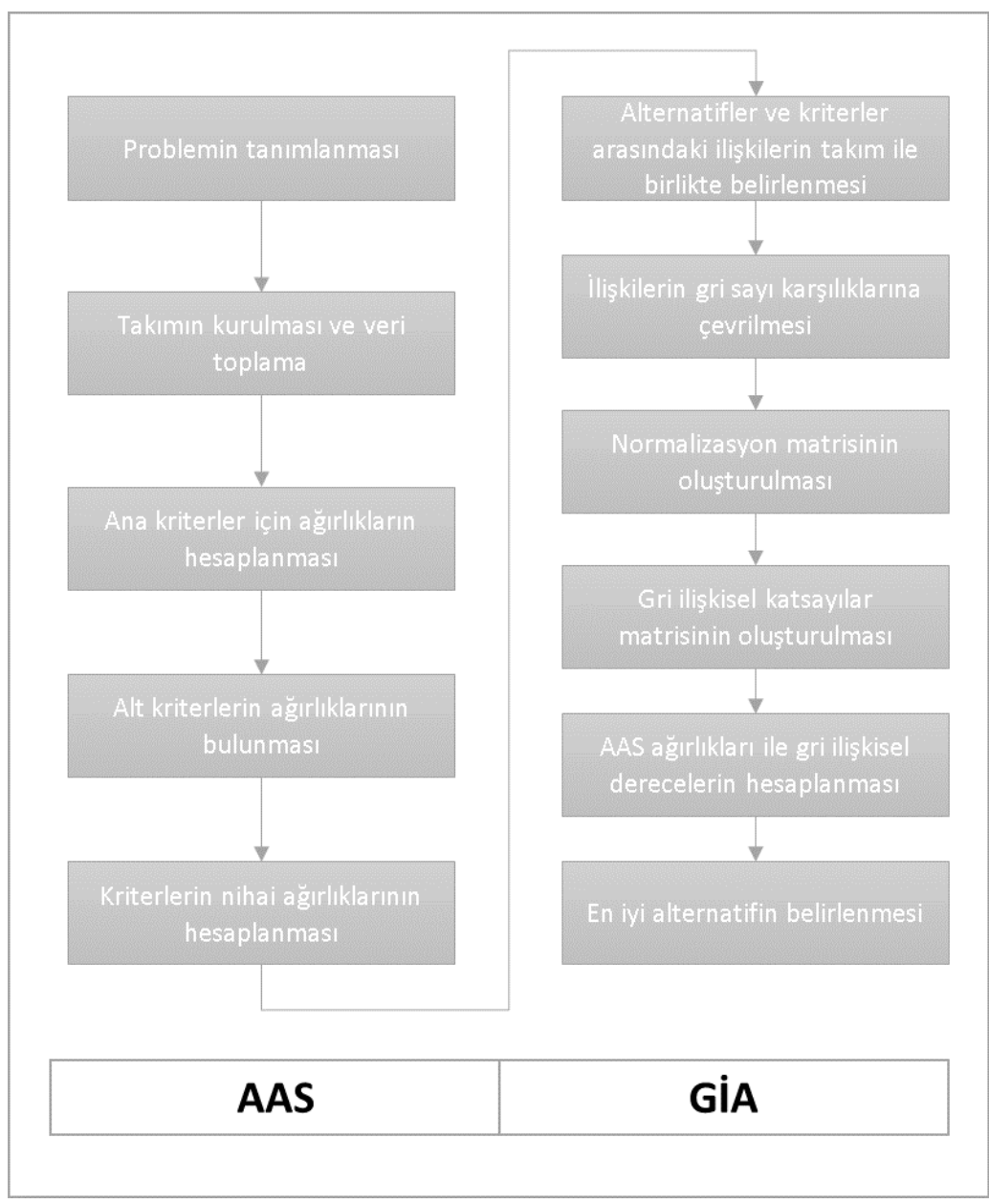

Şekil 2. En İyi Alternatifin Seçiminde İzlenen Așamalar

\section{Takımın kurulması ve Veri Toplama}

Paketleme makinesi seçimi için olușturulan proje takımına biri proje yöneticisi olmak üzere firmada çalşan toplam dört kişi seçilmiştir. Ayrıca proje ekibine iki de akademisyen dahil edilmiştir. Böylece toplam altı kişilik takımın bir araya gelmesi ile birlikte depo tesisine alınacak paketleme makinesi seçimi için öncelikle 8 makine alternatifi belirlenmiş ve ilk toplantıda bu alternatifler 3 makine alternatifine indirilmiştir. Sonrasında bu alternatiflerin değerlendirilmesinde etkili olan kriterler ve alt kriterler belirlenmiştir. Tablo 4'te literatür taraması ve ekip üyelerinin deneyimleri ile belirlenen maliyet, performans, esneklik ve kalite olmak üzere dört ana kriter ve on alt kriter görülmektedir.

Tablo 4. Değerlendirmedeki Kriter ve Alt Kriterler

\begin{tabular}{ccl}
\hline Ana Kriterler & Alt Kriterler & Kisaltmalar \\
\hline Maliyet & Yatırım Maliyeti & YM \\
& Bakım Maliyeti & BM \\
& Yedek Parça Maliyeti & YPM \\
Performans & Hız & H \\
& Duruş Süresi & DS \\
& Setup Süresi & SS \\
Esneklik & Minimum Operatör İhtiyacı & MOİ \\
& Mevcut ürün ve deste boyutuna Uygunluk & MÜDB \\
Kalite & Satış sonrası destek & SSD \\
& Hata Yüzdesi & HY \\
\hline \hline
\end{tabular}




\section{Verilerin Analizi}

Belirlenen dört ana kriterin birbirini etkilemesinden dolayı analitik ağ süreci yöntemi yardımı ile ana kriterlerin ve alt kriterlerin ağırlıklarını bulmak amacı ile Super Decisions programında dört seviyeli ăg yapisı oluşturulmuştur. Karar verme probleminin ana amacı depo tesisine alınacak en iyi paketleme makinesini alternatifler arasından seçmektir. Şekil 3’te görülen ağ yapısındaki tek yönlü ve çift yönlü oklar, ana kriterlerin en iyi makine seçiminde etkili olduğunu ve alt kriterlerin birbirini nasıl etkilediğini göstermektedir. Alternatif ağılıklarının çalışmanın ilerleyen aşamalarında GİA yöntemi ile belirlenecek olmasından dolayı ağ yapısında oklar ile amaca bağlanmamış şekilde görülmektedir.

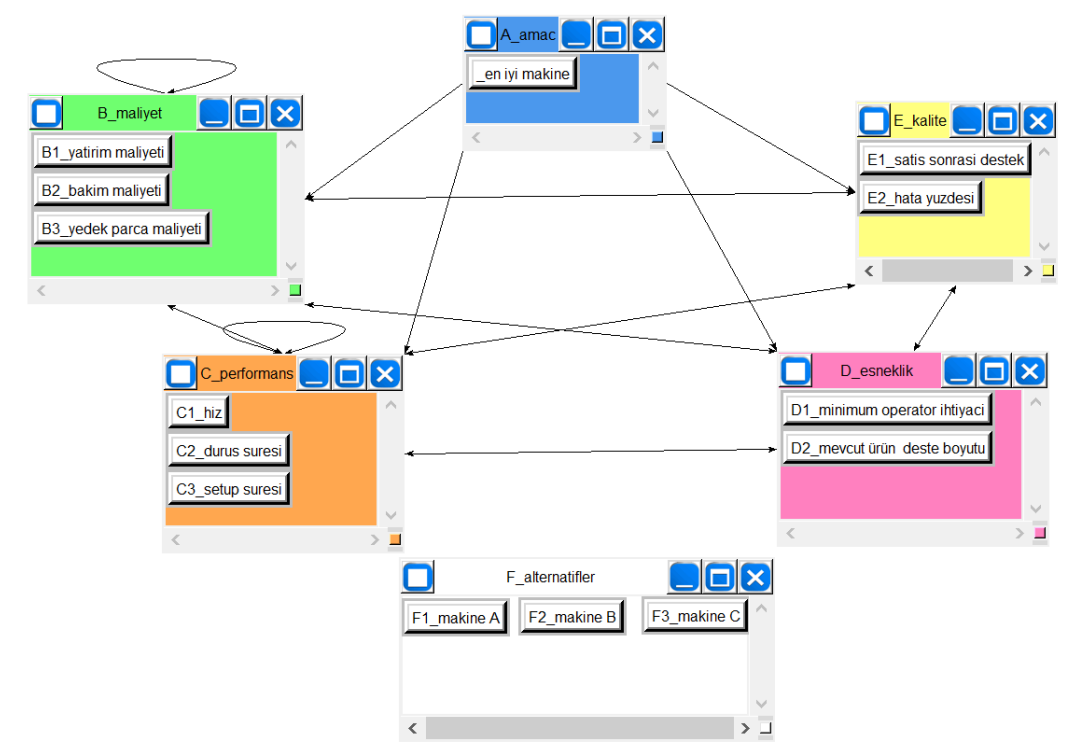

Şekil 3. En İyi Makine Seşiminde Dikkkate Alman Kriterler için A ̆g Yapısı

\section{Ana Kritetler için Ă̆ıtlıklann Hesaplanması}

Maliyet, performans, esneklik ve kalite olmak üzere belirlenen dört ana kriterin ikili karşılaştırılmasında Tablo 1'de yer alan Saaty ölçeği değerleri kullanılmıştır. Bu noktada altı kişiden oluşan proje takımı Saaty ölçeğini kullanarak karşılaştırmalarda ortak karar almışlardır. Tablo 5'te ana kriterlerin karşılaştırma matrisi ve Super Decisions programında hesaplanan ağırlıkları görülmektedir.

Tablo 5. Ana Kriterlerin Karşzlaștırma Matrisi

\begin{tabular}{llllll}
\hline Ana Kriterler & Maliyet & Performans & Esneklik & Kalite & Ağırlıklar \\
\hline Maliyet & 1 & $1 / 3$ & 5 & 3 & 0,262 \\
Performans & 3 & 1 & 7 & 5 & 0,565 \\
Esneklik & $1 / 5$ & $1 / 7$ & 1 & $1 / 3$ & 0,055 \\
Kalite & $1 / 3$ & $1 / 5$ & 3 & 1 & 0,117 \\
\hline
\end{tabular}

Tutarll1lk Oranı: 0,04

Yapılan hesaplamalar sonrasında, en yüksek ağıllı̆̆a performans kriterinin sahip olduğu ortaya çıkmıştır. İkinci sırada maliyet, üçüncü sırada kalite, son sırada ise esneklik kriteri yer almaktadır. Şekil 2'de de görüldügü gibi birbirini etkileyen kriterler de vardır. Alternatiflerin derecelendirilmesinde kriterlerin birbiri ile iliş̧kisi olmadığını varsayarak hesaplanan bu ağılılklara ilave olarak kriterlerin birbirine etkisini dikkate alan kıyaslamalar da yapılmıştır. Sonrasında alt kriter ağırlıklarının bulunmasına geçilmiştir.

\section{Alt Kriterlerin Ağırlıklarının Bulunması}

Bu aşamada, her bir ana kriterin altında yer alan alt kriterlerin ağıllıkları hesaplanmıştır. Tablo 6'da maliyet ana kriterinin altında yer alan üç alt kriterin ikili karşılaştırma matrisi ve ağırlıkları yer almaktadır. En yüksek ağırlığa sahip olan kriterin yatırım maliyeti olduğu görülmektedir. Tablo 7'de yer alan performans kriterinin alt kriter karşılaştırmalarına ve ağırlıklarına bakıldığı zaman ise, en yüksek ağırlığa sahip alt kriter hız olarak karşımıza çıkmaktadır. Tablo 8'de esneklik, Tablo 9'da da kalite kriterlerinin alt 
kriter ağırlıkları yer almaktadır. En yüksek ağırlı̆ga sahip esneklik alt kriteri mevcut ürün deste boyutuna uygunluk iken kalitenin altında yer alan satış sonrası destek ve hata yüzdesi alt kriterleri eşit ağırlıkları sahiptir. İkili karşılaştırmalar sonrasında tutarlılık oranlarının 0,10'un altında olması nedeni ile değerlendirmeler yeterli olarak varsayılmıştır.

Tablo 6. Maliyet Kriterinin Alt Kriterleri için İkili Karşılaştırma Matrisi

\begin{tabular}{lllll}
\hline $\begin{array}{l}\text { Maliyet Kriterinin Alt } \\
\text { Kriterleri }\end{array}$ & YM & BM & YPM & Ağırlıklar1 \\
\hline YM & 1 & 7 & 9 & 0,793 \\
BM & $1 / 7$ & 1 & 2 & 0,131 \\
YPM & $1 / 9$ & $1 / 2$ & 1 & 0,076 \\
\hline Tutarlilik Oran1:0,02 & & & \\
\hline
\end{tabular}

Tablo 7. Performans Kriterinin Alt Kriterleri için İkili Karşılaştırma Matrisi

\begin{tabular}{lllll}
\hline $\begin{array}{l}\text { PerformansKriterinin Alt } \\
\text { Kriterleri }\end{array}$ & H & SS & DS & Ağırlıklar1 \\
\hline H & 1 & 7 & 9 & 0,789 \\
SS & $1 / 7$ & 1 & 3 & 0,149 \\
DS & $1 / 9$ & $1 / 3$ & 1 & 0,066 \\
\hline Tutarlllk Oran1:0,07 & & & \\
\hline
\end{tabular}

Tablo 8. Esneklik Kriterinin Alt Kriterleri için İkili Karşılaștırma Matrisi

\begin{tabular}{llll}
\hline Esneklik Kriterinin Alt Kriterleri & MOİ & ÜDBU & Ă̆ırlıkları \\
& & & \\
\hline MOİ & 1 & $1 / 5$ & 0,167 \\
MÜDB & 5 & 1 & 0,833 \\
\hline Tutarlılık Oran1:0,00 & & & \\
\hline
\end{tabular}

Tablo 9. Kalite Kriterinin Alt Kriterleri için İkili Karşılaștırma Matrisi

\begin{tabular}{llll}
\hline Kalite Kriterinin Alt Kriterleri & SSD & HY & Ağıllıkları \\
\hline SSD & 1 & 1 & 0,50 \\
HY & 1 & 1 & 0,50 \\
\hline Tutarll11k Oranı:0,00 & & & \\
\hline
\end{tabular}

\section{Kriterlerin Nihai Ağırlıklanının Hesaplanması}

Analitik ağ sürecinin son aşamasında ise Super Decisions paket programı kullanılarak elde edilen ağırlıklandırılmıss süpermatris Tablo 10'da, Limit süper matris ise Tablo 11'de görülmektedir.

Tablo 10. Ağırlkelandırlmıs Süpermatris

\begin{tabular}{|c|c|c|c|c|c|c|c|c|c|c|c|c|}
\hline & & \multicolumn{3}{|c|}{ Maliyet } & \multicolumn{3}{|c|}{ Performans } & \multicolumn{3}{|c|}{ Esneklik } & \multicolumn{2}{|l|}{ Kalite } \\
\hline & & Amaç & $\mathrm{YM}$ & $\mathrm{BM}$ & YPM & $\mathrm{H}$ & DS & SS & MOİ & ÜDBU & SSD & $\mathrm{HY}$ \\
\hline & Amaç & 0.000 & 0.000 & 0.000 & 0.000 & 0.000 & 0.000 & 0.000 & 0.000 & 0.000 & 0.000 & 0.000 \\
\hline \multirow{3}{*}{ 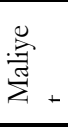 } & $\mathrm{YM}$ & 0.208 & 0.000 & 0.000 & 0.000 & 0.342 & 0.062 & 0.287 & 0.405 & 0.318 & 0.096 & 0.052 \\
\hline & $\mathrm{BM}$ & 0.034 & 0.000 & 0.000 & 0.091 & 0.057 & 0.185 & 0.072 & 0.000 & 0.055 & 0.048 & 0.052 \\
\hline & YPM & 0.020 & 0.000 & 0.091 & 0.000 & 0.033 & 0.185 & 0.072 & 0.000 & 0.033 & 0.048 & 0.052 \\
\hline \multirow{3}{*}{ 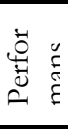 } & $\mathrm{H}$ & 0.443 & 0.453 & 0.139 & 0.167 & 0.000 & 0.162 & 0.291 & 0.288 & 0.089 & 0.000 & 0.51 \\
\hline & DS & 0.084 & 0.117 & 0.418 & 0.383 & 0.162 & 0.000 & 0.032 & 0.096 & 0.075 & 0.808 & 0.097 \\
\hline & SS & 0.037 & 0.050 & 0.139 & 0.146 & 0.162 & 0.161 & 0.000 & 0.096 & 0.317 & 0.000 & 0.055 \\
\hline \multirow{2}{*}{ [I } & MOİ & 0.009 & 0.095 & 0.000 & 0.000 & 0.022 & 0.022 & 0.022 & 0.000 & 0.000 & 0.000 & 0.154 \\
\hline & MÜDB & 0.046 & 0.094 & 0.000 & 0.000 & 0.065 & 0.065 & 0.065 & 0.000 & 0.000 & 0.000 & 0.031 \\
\hline \multirow{2}{*}{$\ddot{\mathscr{V}} \pm$} & SSD & 0.059 & 0.032 & 0.106 & 0.170 & 0.040 & 0.027 & 0.080 & 0.028 & 0.057 & 0.000 & 0.000 \\
\hline & $\mathrm{HY}$ & 0.059 & 0.158 & 0.106 & 0.042 & 0.119 & 0.133 & 0.080 & 0.085 & 0.057 & 0.000 & 0.000 \\
\hline
\end{tabular}


Tablo 11. Limit Süpermatris

\begin{tabular}{|c|c|c|c|c|c|c|c|c|c|c|c|c|}
\hline & & \multicolumn{3}{|c|}{ Maliyet } & \multicolumn{4}{|c|}{ Performans } & \multicolumn{2}{|c|}{ Esneklik } & \multicolumn{2}{|l|}{ Kalite } \\
\hline & & Amaç & $\overline{\mathrm{YM}}$ & $\mathrm{BM}$ & YPM & $\overline{\mathrm{H}}$ & $\overline{\mathrm{DS}}$ & $\overline{S S}$ & MOİ & ÜDBU & SSD & $\overline{\mathrm{HY}}$ \\
\hline & Amaç & 0.000 & 0.000 & 0.000 & 0.000 & 0.000 & 0.000 & 0.000 & 0.000 & 0.000 & 0.000 & 0.000 \\
\hline \multirow{3}{*}{ 氞! } & $\mathrm{YM}$ & 0.156 & 0.156 & 0.156 & 0.156 & 0.156 & 0.156 & 0.156 & 0.156 & 0.156 & 0.156 & 0.156 \\
\hline & $\mathrm{BM}$ & 0.065 & 0.065 & 0.065 & 0.065 & 0.065 & 0.065 & 0.065 & 0.065 & 0.065 & 0.065 & 0.065 \\
\hline & YPM & 0.060 & 0.060 & 0.060 & 0.060 & 0.060 & 0.060 & 0.060 & 0.060 & 0.060 & 0.060 & 0.060 \\
\hline \multirow{3}{*}{ 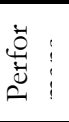 } & $\mathrm{H}$ & 0.213 & 0.213 & 0.213 & 0.213 & 0.213 & 0.213 & 0.213 & 0.213 & 0.213 & 0.213 & 0.213 \\
\hline & DS & 0.162 & 0.162 & 0.162 & 0.162 & 0.162 & 0.162 & 0.162 & 0.162 & 0.162 & 0.162 & 0.162 \\
\hline & SS & 0.111 & 0.111 & 0.111 & 0.111 & 0.111 & 0.111 & 0.111 & 0.111 & 0.111 & 0.111 & 0.111 \\
\hline & MOİ & 0.040 & 0.040 & 0.040 & 0.040 & 0.040 & 0.040 & 0.040 & 0.040 & 0.040 & 0.040 & 0.040 \\
\hline & MÜDB & 0.049 & 0.049 & 0.049 & 0.049 & 0.049 & 0.049 & 0.049 & 0.049 & 0.049 & 0.049 & 0.049 \\
\hline \multirow{2}{*}{$\tilde{U}:$} & SSD & 0.048 & 0.048 & 0.048 & 0.048 & 0.048 & 0.048 & 0.048 & 0.048 & 0.048 & 0.048 & 0.048 \\
\hline & $\mathrm{HY}$ & 0.096 & 0.096 & 0.096 & 0.096 & 0.096 & 0.096 & 0.096 & 0.096 & 0.096 & 0.096 & 0.096 \\
\hline
\end{tabular}

Şekil 4'te kriterlerin birbiri ile ilişkisinin de göz önünde bulundurulmasıyla hesaplanan nihai kriter ağırlıkları olan Super Decisions programının ekran görüntüsü yer almaktadır. Normalized by cluster sütunu alt kriterlerin kendi kriterleri içindeki ağıllığını vermektedir. Örneğin Maliyet kriteri içindeki alt kriterlerden yatırım maliyeti 0,55545 , bakım maliyeti 0,23228 ve yedek parça maliyeti 0,21226 ağırlığına sahiptir. Limiting sütununda yer alan değerler ise 10 alt kriterin nihai ağırlı̆̆ını göstermektedir. Bu sütuna dikkat edilirse bazı değerlerin 0 olduğu görülebilir. Bu durum Super Decisions programındaki alternatiflerin seçimi yapılmadığından, sadece kriter ağırlıklarına ihtiyaç duyulduğundan oluşmuştur. Alt kriterlerin öncelikleri incelendiğinde; depo için en uygun paketleme makinesinin seçimini en fazla etkileyen alt kriterin 0,213012 ağırlığına sahip olan hız kriteri olduğu, ikinci sırada 0,161746 değeri ile duruş süresi alt kriterinin, son sırada ise; satış sonrası destek alt kriterinin yer aldığ görülmektedir. Analitik ağ süreci ile bulunan kriter ağırlıkları, gri ilişkisel derecelerin hesaplanmasında katsayı olarak kullanılmış, bu dereceler ile firmanın en uygun makine seçimi kararını vermesinde yardımcı olunmuştur.

\begin{tabular}{|c|c|c|c|}
\hline \multicolumn{4}{|c|}{ Here are the priorities. } \\
\hline Icon & Name & Normalized by Cluster & Limiting \\
\hline No Icon & _en iyi makine & 0.00000 & 0.000000 \\
\hline No Icon & B1_yatirim maliyeti & 0.55545 & 0.156128 \\
\hline No Icon & B2_bakim maliyeti & 0.23228 & 0.065291 \\
\hline No Icon & B3_yedek parca maliyeti & 0.21226 & 0.059664 \\
\hline No Icon & C1_hiz & 0.43847 & 0.213012 \\
\hline No Icon & C2_durus suresi & 0.33295 & 0.161746 \\
\hline No Icon & C3_setup suresi & 0.22858 & 0.111045 \\
\hline No Icon & $\begin{array}{l}\text { D1_minimum operator } \\
\text { ihtiyaci }\end{array}$ & 0.44892 & 0.040139 \\
\hline No Icon & $\begin{array}{l}\text { D2_mevcut ürün deste } \\
\text { boyutu }\end{array}$ & 0.55108 & 0.049273 \\
\hline No Icon & E1_satis sonrasi destek & 0.33119 & 0.047593 \\
\hline No Icon & E2_hata yuzdesi & 0.66881 & 0.096108 \\
\hline No Icon & F1_makine A & 0.00000 & 0.000000 \\
\hline No Icon & F2_makine B & 0.00000 & 0.000000 \\
\hline No Icon & F3_makine C & 0.00000 & 0.000000 \\
\hline
\end{tabular}

Şekil 4. Analitik Ağ Sürecine Göre Öncelikler Tablosu

GİA yönteminin ilk aşamasında takım bir araya gelmiş ve en uygun paketleme makinesi için söz konusu olan üç alternatifi on kritere göre değerlendirmiştir. Alternatiflerin kriterlere göre değerlendirilmesinde Tablo 3'de yer alan kısaltmalar kullanılmıştır. Değerlendirmelerin sonucunun yer aldığı karar matrisi ise Tablo 12'de görülmektedir. 
Tablo 12. Alternatifler ve Kriterler Arasi İliski Matrisi

\begin{tabular}{|c|c|c|c|}
\hline KRİTERLER & Makine A & Makine B & Makine C \\
\hline B1_yatirim maliyeti & $\bar{G}$ & $\bar{F}$ & G \\
\hline B2_bakim maliyeti & VP & $\mathrm{F}$ & MP \\
\hline B3_yedek parca maliyeti & VP & $\mathrm{F}$ & MP \\
\hline C1_hiz & VG & $\mathrm{F}$ & $\mathrm{F}$ \\
\hline C2_durus suresi & VG & G & MG \\
\hline C3_setup suresi & MP & MG & MG \\
\hline D1_minimum operator ihtiyaci & VG & $\mathrm{F}$ & G \\
\hline D2_mevcut ürün deste boyutu & VG & MG & VG \\
\hline E1_satis sonrasi destek & VP & $\mathrm{F}$ & $\mathrm{P}$ \\
\hline E2_hata yuzdesi & G & VG & G \\
\hline
\end{tabular}

Karar matrisinde yer alan ifadelerin gri karşllı̆̆ için Tablo 3'de görülen Li ve arkadaşlarının 2007 yılında yaptıkları çalışmada yer alan gri karşıllkklar kullanılmıştır. Her bir kriterin maksimum değeri belirlenerek referans serisi oluşturulmuştur. Bir sonraki aşamada ise normalizasyon işlemi gerçekleştirilmiştir. Matriste yer alan değerin maksimum düzeyde olması isteneceğinden, normalizasyon işleminde eşitlik 3 kullanılmıştır. Mutlak değer tablosu oluşturma aşamasında ise eşitlik 7 kullanılmıştır. GİA yönteminin son aşamasında; gri ilişkisel derecelerin hesaplanması için kriterlerin AAS ile elde edilen ağırlıkları kullanılmış ve eşitlik 11 kullanılarak, Tablo 13’te yer alan gri ilişkisel katsayı matris değerleri kriter ağırlıkları ile çarpılmıştır.

Tablo 13. Gri Ilişkisel Katsaynlar Matrisi

\begin{tabular}{lllllllllll}
\hline KRİTERLER & YM & BM & YPM & H & DS & SS & MOİ & MÜDB & SSD & HY \\
\hline Makine a & 1 & 0,333 & 0,333 & 1 & 1 & 0,333 & 1 & 1 & 0,3333 & 0,333 \\
Makine b & 0,33 & 1 & 1 & 0,333 & 0,500 & 1 & 0,33 & 0,333 & 1 & 1 \\
Makine c & 1 & 0,667 & 0,667 & 0,333 & 0,333 & 1 & 0,556 & 1 & 0,444 & 0,333 \\
\hline \hline
\end{tabular}

\section{Bulgular}

Analiz aşamasında elde edilen matris değerleri kriter ağırlıklanı ile çarpılarak Tablo 14'te görülen gri ilişkisel dereceler elde edilmiştir. Tablo 15 ise bütün kriterler eşit öneme sahip olsaydı hangi makine alternatifi seçilirdi sorusuna cevap vermek için oluşturulmuştur. Üç farklı markayı içeren makine alternatiflerinden AAS ağırlıklarına göre hesaplamayı içeren Tablo 14'ten anlaşılacağı üzere, en yüksek gri ilişki derecesine $(0,75)$ sahip olan A makinesi en iyi alternatif olarak görülmektedir. B ve C makinesi alternatifleri ise 0,61 ve 0,60 derecelerle birbirine yakın alternatiflerdir. Ancak A makinesi ile aralarındaki fark birbirlerine oranla daha fazladır.

Tablo 14. AAS Ağrrlıklar ile Hesaplanan Gri Iliskisel Dereceler

\begin{tabular}{|c|c|c|c|c|c|c|c|c|c|c|c|c|}
\hline \multirow{2}{*}{$\begin{array}{c}\text { Kriterler } \\
\text { ve AAS } \\
\text { katsayıları }\end{array}$} & $\overline{Y M}$ & $\overline{\mathbf{B M}}$ & YPM & $\mathbf{H}$ & DS & SS & MOİ & $\begin{array}{l}\text { MÜD } \\
\text { B }\end{array}$ & SSD & $\overline{\mathrm{HY}}$ & & \\
\hline & 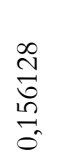 & 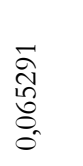 & 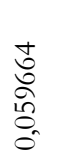 & 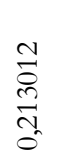 & $\begin{array}{l}\stackrel{0}{+} \\
\stackrel{5}{0} \\
\stackrel{-}{0}\end{array}$ & $\begin{array}{l}\stackrel{20}{0} \\
\stackrel{\Xi}{=} \\
0\end{array}$ & 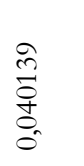 & 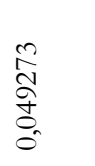 & 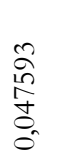 & $\begin{array}{l}\infty \\
0 \\
0 \\
0 \\
0 \\
0 \\
0\end{array}$ & 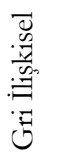 & 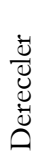 \\
\hline Makine A & 1 & 0,333 & 0,333 & $\overline{1}$ & 1 & 0,333 & $\overline{1}$ & 1 & 0,333 & 0,333 & 0,75 & \\
\hline Makine B & 0,333 & 1 & 1 & 0,333 & 0,500 & 1 & 0,333 & 0,333 & 1 & 1 & 0,61 & \\
\hline Makine C & 1 & 0,667 & 0,667 & 0,333 & 0,333 & 1 & 0,556 & 1 & 0,444 & 0,333 & 0,60 & \\
\hline
\end{tabular}

Tablo 15. Eșit ağrrlkklar ile Hesaplanan Gri İliskisel Dereceler

\begin{tabular}{|c|c|c|c|c|c|c|c|c|c|c|c|c|}
\hline $\begin{array}{l}\text { Kriterler } \\
\text { ve } \\
\text { katsayıları }\end{array}$ & $\mathbf{Y M}$ & $\mathbf{B M}$ & YPM & $\overrightarrow{0}$ & DS & $\overrightarrow{0}$ & MOİ & $\begin{array}{l}\text { MÜDD } \\
\text { B }\end{array}$ & SSD & $\mathbf{H Y}$ & 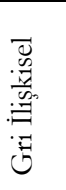 & 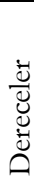 \\
\hline Makine A & 1 & 0,333 & 0,333 & 1 & 1 & 0,333 & 1 & 1 & 0,333 & 0,333 & 0,67 & \\
\hline Makine B & 0,333 & 1 & 1 & 0,333 & 0,500 & 1 & 0,333 & 0,333 & 1 & 1 & 0,68 & \\
\hline Makine C & 1 & 0,667 & 0,667 & 0,333 & 0,333 & 1 & 0,556 & 1 & 0,444 & 0,333 & 0,63 & \\
\hline
\end{tabular}


Bütün kriterlere eşit ağıllk vererek seçim yapmak ise proje takımı tarafından uygun görülmemiştir. Özellikle en düşük nihai ağırlıklara sahip minimum operatör ihtiyacı $(0,04)$ ve satış sonrası destek $(0,05)$ gibi kriterlerin ağırlıklarını 0,10 'a çıkarırken, hız $(0,21)$, duruş süresi $(0,16)$ ve yatırım maliyeti $(0,15)$ gibi kriter ağırlıklarını 0,10'a indirmek paketleme makinesi seçim problemine sı̆̆ bir bakış olarak görülmüştür. Nitekim Tablo 15'e bakıldığında alternatiflerin gri ilişkisel derecelerinin birbirine çok yaklaştı̆̆ ve B makinesinin 0,68 ile en yüksek gri ilişkisel dereceye sahip olduğu tablodan görülebilir. Buna göre proje takımı AAS ağırlıklarını dikkate alarak hesaplanan gri ilişkisel dereceleri dikkate alarak A makinesinde karar kilmıştır.

\section{Tartı̧̧ma, Sonuç ve Öneriler}

Tedarik zinciri yönetimi, ürünün hammadde aşamasından, nihai tüketiciye ulaştırılması aşamasına kadar ki süreçlerin hepsini kapsamaktadır. Tedarik zinciri üzerindeki mal hareketi farklı amaçlarla depolarda durdurulmaktadır. Depolama işleminin verimli ve etkin bir şekilde yerine getirilmesi ürünün nihai tüketiciye doğru akışının düzenli hale getirilmesini sağlayarak, işletmelerin performansını da doğrudan etkilemektedir. Ürünler bekletilirken, palet açma, paketleme, etiketleme, bandrolleme gibi birtakım operasyonlar depolama sırasında yapılabilmektedir. Bu çalışmada da ÇKKV tekniklerinden AAS ile GİA yöntemleri entegre bir şekilde kullanılarak bir firmanın deposunda kullanılmak üzere satın almayı düşündüğ̈̈ üç alternatif makine arasından en uygununun belirlenmesine çalışılmıştır. Makinenin satın alınmasında etkili olan ana kriterlerin ve alt kriterlerin belirlenmesi ve bu kriterlerin ağırlıklarının ortaya konması için AAS kullanılmıştır. AAS yönteminde kriterlerin kendi aralarındaki etkileşimi de göz önünde bulundurulmuştur. Proje takımı ile yapılan görüşmeler sonucunda performans ana kriterinin diğer ana kriterlere göre daha önemli olduğu vurgulanmıştır. Buna göre performans kriteri önem derecesi açısından \%50'den daha büyük bir öneme sahip olduğu belirlenmiştir.

Makine alternatifleri arasından en uygun makinenin seçimi sırasında dikkate alınan kriterlerin her biri karar vericinin gözünde eşit ağıllıkta olabileceği gibi farklı ağıllıklara da sahip olabilmektedir. Bu çalışmada yer alan karar verme probleminde, her bir kriterin yöneticilerin gözünde farklı öneme sahip olduğunun anlaşılması sebebi ile GİA yöntemi ile en uygun makinenin seçilmesinde AAS ile elde edilen kriter ağırlıkları kullanılmıştır. GİA sonrasında depolarda paketleme işlevini yerine getirecek en uygun makinenin A makinesi olduğu sonucuna varılmıştır. İşletme yönetimi uygulama sonrası elde edilen sonuçları tatmin edici bulmuş, depoda paketleme işlemini yerine getirmek için A makinesini almaya karar vermiştir.

Literatürde alternatifler arasından en uygun olanının seçilmesi sırasında ortaya çıkan karar verme problemleri için, çok sayıda yöntem tek başına ya da farklı yöntemlerle entegre bir şekilde kullanılmaktadır. Bu çalışmadan elde edilen bulgular ve literatür taraması sonuçları ile de makine seçimi ve benzeri ÇKKV problemlerinin ÇKKV tekniklerinden AAS ve GİA yöntemlerinin entegre bir şekilde kullanılması ile çözülebileceği ortaya konmuştur. Bundan sonraki çalışmalarda ELECTRE, TOPSİS, VIKOR gibi ÇKKV teknikleri ile benzer ya da farklı sonuçlar ortaya konabileceği araştırılabilir.

\section{Etik Beyan}

"Bir Depo Tesisine Alnacak Paketleme Makinesi Seçim Kararnm Analitik. Ăg Süreci Tabanh Gri Illiskisel Analiz, Yöntemiyle Belirlenmesi” başlıklı çalışmanın yazım sürecinde bilimsel kurallara, etik ve alıntı kurallarına uyulmuş; toplanan veriler üzerinde herhangi bir tahrifat yapılmamış ve bu çalışma herhangi başka bir akademik yayın ortamına değerlendirme için gönderilmemiştir. Bu araştırmada hazır veri seti kullanıldığ1 için etik kurul kararı zorunluluğu taşımamaktadır.

\section{Kaynakça}

Ayağ, Z. ve Özdemir, R. G. (2012). Evaluating machine tool alternatives through modified TOPSIS and alpha-cut based fuzzy ANP, Production Economics, 140, 630-636

Ayağ, Z. ve Yücekaya, A. (2019). A fuzzy ANP based GRA approach to evaluate ERP Packages, International Journal of Enterprise Information Systems (IJEIS), 15(1), 45-68

Aydemir, E., Bedir, F. ve Özdemir, G. (2013). Gri Sistem, Teorisi ve Uygulamaları: Bilimsel Yazın Taramas1, Süleyman Demirel Üniversitesi İktisadi ve İdari Bilimler Fakültesi Dergisi, 18(3), 187-200.

Baset, M. A., Chang, V., Gamal, A. ve Smarandache F. (2019). An integrated neutrosophic ANP and VIKOR method for achieving sustainable supplier selection: A case study in importing field, Computer in Industry, 106, 94-110.

Chang, C. L, Tsai, C. H. ve Chen, L. (2003). Applying grey relational analysis to the decathlon evaluation model, International Journal of The Computer, The Internet and Management, 11(3), 54-62. 
Çakir, S. ve Perçin, S. (2013). Çok kriterli karar verme teknikleriyle lojistik firmalarinda performans ölçümü, Ege Akademik Bakıs, 4(13), 449-459

Demir, G., Hüdaverdi, B. ve Dündar S. (2020). Bireysel emeklilik sistemindeki şirketlerin performanslarının gri ilişkisel analizle ölçülmesi ve bir uygulama, Manisa Celal Bayar Üniversitesi Sosyal Bilimler Dergisi, 18(2), 155-170

Deng, J. L. (1989). Introduction of grey system theory, The Journal of Grey Systems, 1-24.

Ersoy, N. (2020). Finansal performansın gri ilişkisel analiz yöntemi ile değerlendirilmesi: Borsa İstanbul Ulaştırma Endeksi'ndeki şirketler üzerine bir araştırma, Mubasebe ve Finansman Dergisi, 86, 223-246

Ertuğrul, İ. (2007). Bulanık analitik hiyerarşi süreci ve bir tekstil işletmesinde makine seçim problemine uygulanması, H.Ü. İktisadi ve İdari Bilimler Fakü̈ltesi Dergisi, 25(1), 171-192

Giannakis, M., Dubey, R., Vlachos, I. ve Ju, Y. (2020). Supplier sustainability performance evaluation using the analytic

network process., Journal of Cleaner Production, 247, 119439

Gür, Ş., Miman, M. ve Eren, T. (2020). Analitik ağ süreci yöntemi ile akaryakıt taşımacılı̆̆ının çevresel etkilerini değerlendirme, Harran Üniversitesi Mühendislik Dergisi, 5(2), 61-70

Hashemi S. H., Karimi, A., \& Tavana, M. (2015). n integrated green supplier selection approach with analytic network process and improved grey relational analysis, Production Economics, 159, 178-191.

Im, K., \& Cho, H. (2020). Towards successful business model management with analytic network process-based feasibility evaluation and portfolio, Eltronic Markets, 30, 509-523.

Kabak, M., ve Dağdeviren, M. (2017). A Hybrid approach based on ANP mnd grey relational analysis for machine selection. Tehnicki vjesnik./Technical Gazette, 24, 109-118

Karim, R. ve Karmaker, C. L. (2016). Machine selection by AHP and TOPSIS methods, American Journal of Industrial Engineering, 4(1) , 7-13

Keskin, N., Kıran, A. N., Eğdemir, K. ve Eren, T. (2020). Bulut bilişim güvenlik gereksinimlerine göre çok ölçütlü karar verme yöntemleri ile hizmet sağlayıcı seçimi, Uluslararası Bilgi Güvenlĭ̈i Mühendisliği Dergisi, 1(6), 45-60.

Kumru, M ve Kumru, Y. (2015). A fuzzy ANP model for the selection of 3D coordinate-measuring machine, Intell Manufacturing, 26, 999-1010.

Li, G. D., Yamaguchi, D. ve Nagai, M. (2007). A grey-based decision-making approach to the supplier selection problem. Mathematical and computer modelling, 46, 573-581.

Matin, A., Zare, S., Ghotbi-Ravandi, M. ve Jahani, Y. (2020). Prioritizing and weighting determinants of workers' heat stress control using an analytical network process (ANP) a field study, Urban Climate 31.

Ömürbek, N. ve Şimşek, A. (2014). Analitik hiyerarşi süreci ve analitik ă̆ süreci yöntemleri ile online alişveriş site seçimi. Yönetim ve Ekonomi Arașturmalar Dergisi, 22(12), 306-327.

Özbek, A. (2017). Cok Kriterli Karar Verme Yöntemleri ve Excel ile Problem Çözümü. Ankara: Seçkin Yayınevi,.

Sarraf, F. ve Nejad, S. H. (2020). Improving performance evaluation based on balanced scorecard with grey relational analysis and data envelopment analysis approaches: Case study in water and wastewater companies, Evaluation and Program Planning, 79, 102-107

Saaty, T. (1986). Axiomatic foundation of the analytic hierarchy process, Management Science, 32(7), 841-855

Saaty, T. L. (2005). Theory and applications of the analytic network process: Decision making with benefits, opportunities, costs, and risks. Pittsburgh: RWS Publications.

Samvedi, A., Jain V. ve Chan T. S. F. (2012). An integrated approach for machine tool selection using fuzzy analytical hierarchy process and grey relational analysis, International Journal of Production Research, 50(12), 3211-3221.

Sert, Y. O., Gür, Ş. ve Eren, T. (2020). Dördüncü sanayi devriminin personel seçimi süreçlerine etkisinin değerlendirilmesi, Erciyes Üniversitesi İ̈BF Dergisi, 55, 191-202.

Siyambaş, Y. ve Turgut, Y. (2020). HSLA çeliğinin delinmesinde kesme parametrelerinin çap değişimi ve çapak yüksekliği üzerindeki etkilerinin gri ilişkisel analiz yöntemiyle araştırılması, Gaz̨i Üniversitesi Fen Bilimleri Dergisi, 8(2), 320-334.

Sridharan, R., Anilkumar, E. N. ve Vishnu, C. R. (2019). Strategic barriers and operational risks in sustainable supply chain management in the Indian context: A grey relational analysis approach. Emerging Applications in Supply Chains for Sustainable Business Development, 238-259

Yıldırım, B. F. ve Önder, E. (2015). İsletmeciler, mühendisler ve yöneticiler için operasyonel ve stratejïk problemlerin çözümünde çok kriterli karar verme teknikleri. Bursa: Dora Yayın Evi.

Zuo, W., Li, J., Zhang, Y., Li, O., Jia, S. ve He, Z. (2020). Multi-factor impact mechanism on combustionefficiency of a hydrogen-fueled micro-cylindrical, International Journal of Hydrogen Energy, 45(3), 2319-2330.

\section{EXTENDED ABSTRACT}

The competitive environment of today's business is getting more and more complex every day. Firms have to meet customer demands and needs for competition, while going beyond customer request. Especially the issue of timely delivery has gained importance among companies to reach the end customer. Timely delivery depends on the integration of the supply chain. Therefore, business success does not only depend on firm's performance, but also depends on the performance of the supply chain members who affect the success of the businesses directly. 
The efficient and effective performance of the storage process ensures that the flow of the product to the end consumer is regulated and directly affects the performance of the enterprises. Some operations such as palletizing, packaging, and labeling can be done during storage, while the products are kept waiting. Especially packaging takes place along the entire supply chain. Packaging, which has a great contribution to promotion efforts in the field of marketing, particularly useful in terms of transportation and storage in the field of logistics. Packaging provides speed and convenience to employees in handling very small products and keeping them in warehouses.

Packaging types differ based on the building-blocks concept, where a small unit is placed in a larger unit and this large unit is placed in a larger unit. In addition, these types are named as primary, secondary, tertiary packaging. The primary packaging is the packaging that wraps and houses the product, while the secondary packaging is often used to group primary packaging and is called a master carton. Due to the need for increased productivity in warehouses, the importance of bundling machines is increasing day by day and these machines are also used in many sector's warehouses to get master cartons. The biggest advantage of bundling machines is that it reduces the need for employees and shortens the process cycle time. These machines differ from each other in terms of many criteria such as size, speed, operator requirement and investment cost. For this reason, warehouse managers and operations managers in companies act according to many criteria while making this big purchasing decision. Choosing the most suitable machine by considering different criteria is one of the multi-criteria decision-making problems for businesses.

This study aimed to help a warehouse manager and project team working in the pharmaceutical industry to choose a bundling machine, which is used in the warehouse. Machine selection decision is a multi-criteria decision so Analytical Network Process and Gray Relational Analysis are used to determine the most suitable machine among three alternative machines.

Analytical network process (ANP) was used to determine the main criteria and sub-criteria that are effective in machine purchasing to reveal the weights of these criteria. Criteria that effects the machine selection are in interactions among themselves so these interactions are considered in ANP as well. Main criteria are cost, performance, flexibility and quality. After Project team interviews and calculations in Super Decisions package program, it is seen that the "performance" criteria is more important criteria than the other main criteria. In addition, when priorities are examined the most effective sub-criteria for the choice of the most suitable bundling machine for the warehouse is the speed criteria and the second is the stop time criteria. "After-sales support" sub-criteria is the least effective criteria.

Each of the criteria taken into consideration during the selection of the most suitable machine among the machine alternatives can have equal weight in the eyes of the decision-maker as well as different weights. The decision-making problem in this study shows that each criteria has different importance in the eyes of team members and managers, thus while using the Gray Relational Analysis to choose the most suitable bundling machine criteria weights the analytical network process were used.

After the Gray Relational Analysis, it was concluded that the most suitable machine to perform the packaging function in the warehouses is the A machine. The business management found the results obtained after the application satisfactory and decided to purchase machine A to fulfill the packaging process in the warehouse.

In the literature, many methods are used in a single or in an integrated manner for decisionmaking problems that arise during the selection of the most suitable alternative. Findings obtained from this study and the results of the literature review revealed that machine selection and similar multi-criteria decision-making problems can be solved by the integrated use of multi-criteria decision making techniques as Analytical Network Process and Grey Relational Analysis methods. In future studies, it can be researched in similar or different results, which can be obtained with multi-criteria decision-making techniques such as ELECTRE, TOPSIS and VIKOR. 